\title{
GAIN'S DEFINITION OF NUTRITIOUS AND SAFE FOODS
}

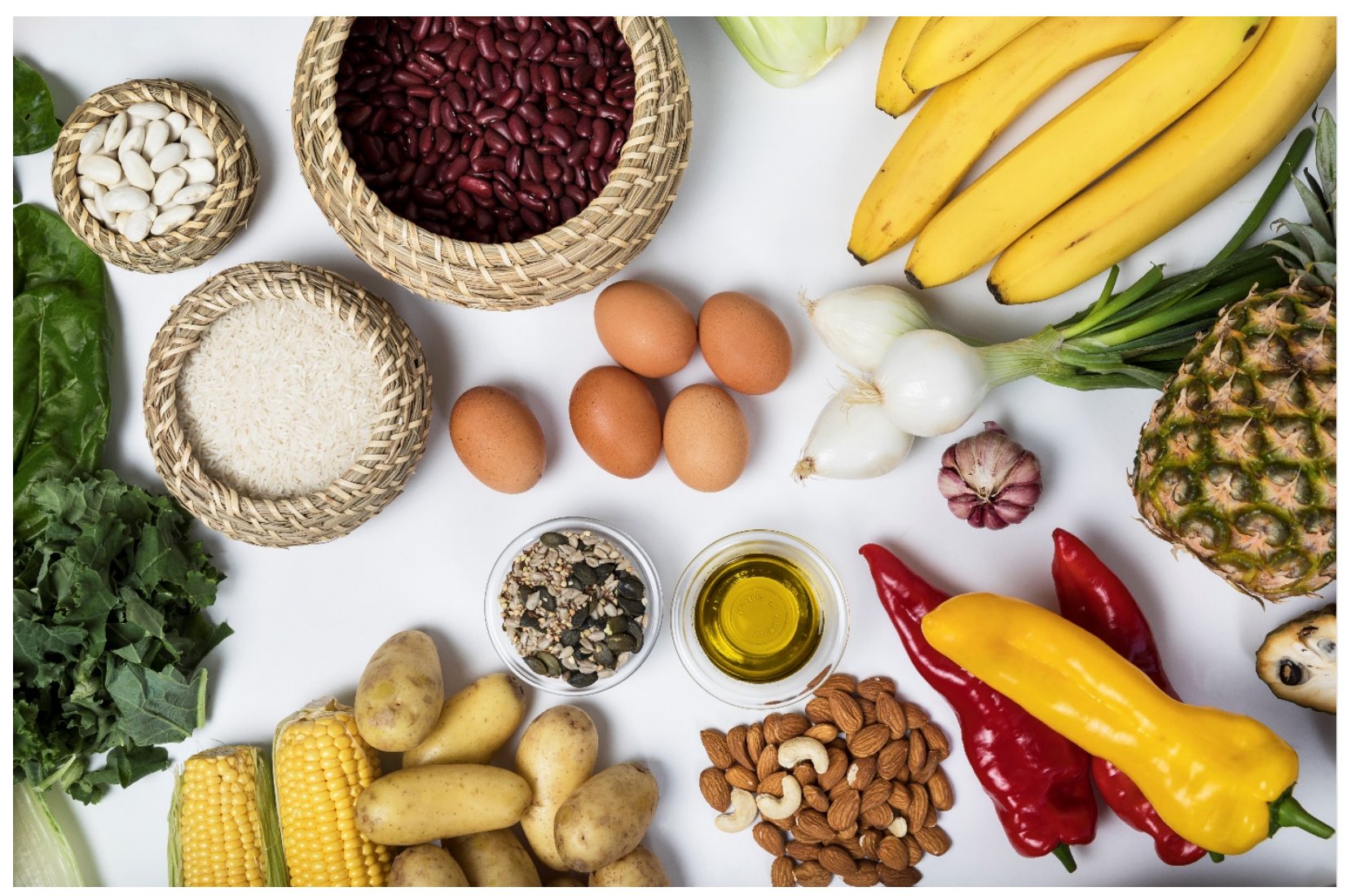

GAIN Briefing Paper $n^{\circ} 8$

December 2021 


\section{ABOUT GAIN}

The Global Alliance for Improved Nutrition (GAIN) is a Swiss-based foundation launched the UN in 2002 to tackle the human suffering caused by malnutrition. Working with governments, businesses and civil society, we aim to transform food systems so that they deliver more nutritious food for all people, especially the most vulnerable.

\section{Recommended citation}

Global Alliance for Improved Nutrition (GAIN). GAIN's Definition of Nutritious and Safe Foods. Global Alliance for Improved Nutrition (GAIN). Briefing Paper \#8. Geneva, Switzerland, 2021. DOI: https://doi.org/10.36072/bp.8

\section{(c) The Global Alliance for Improved Nutrition (GAIN)}

This work is available under the Creative Commons Attribution-Non-Commercial-Share Alike 4.0 IGO licence (CC BY-NC-SA 4.0 IGO; https://creativecommons.org/licenses/by-nc-sa/4.0/). Under the terms of this licence, you may copy, redistribute, and adapt the work for non-commercial purposes, provided the work is appropriately cited, as indicated below. In any use of this work, there should be no suggestion that GAIN endorses any specific organisation, products, or services. The use of the GAIN logo is not permitted. If you adapt the work, then you must license your work under the same or equivalent Creative Commons license. The contribution of third parties do not necessarily represent the view or opinion of GAIN.

\section{Acknowledgements}

This brief was drafted by Flaminia Ortenzi, Christina Nyhus Dhillon, Ty Beal, Stella Nordhagen, Caroline DeWaal, Anthony Wenndt, Elisabetta Lambertini, and Wendy Gonzalez as members of the Nutritious and Safe Foods Definition Working Group. We are grateful for comments and review by Mduduzi Mbuya, Saul Morris, Lawrence Haddad, and Lynnette Neufeld. We also thank Oliver Camp, Kathrin Demmler, Bonnie McClafferty, Sabiha Sultana, Valerie Friesen, and Catia Pedro for contributing to the discussions as part of the Nutritious and Safe Foods Definition Working Group.

\section{GAIN BRIEFING PAPER SERIES}

GAIN Briefing Notes provide essential information in a succinct, accessible form to support informed decision-making by stakeholders in the food system to improve the consumption of nutritious, safe food for all people, especially the most vulnerable.

The Global Alliance for Improved Nutrition (GAIN)

Rue de Varembé 7

1202 Geneva

Switzerland

T: +41 227491850

E: info@gainhealth.org 


\section{SUMMARY}

GAIN's mission and strategy revolve around the core concept of "nutritious and safe foods". In addition, there is a growing consensus that foods should be produced sustainably-i.e., that one should take into account the environmental impact associated with the production of these foods. Regularly achieving alignment and consistency across its programmes in the understanding and implementation of these concepts is of crucial importance to GAIN. This briefing paper aims to share the definition GAIN uses of 'nutritious and safe foods,' present environmental impact levers for sustainable production, and provide relevant examples for guidance. This definition may be useful for others, either as the end point or starting point of an organisation's journey to define nutritious and safe foods. GAIN defines a "nutritious" food as a food that in the context where it is consumed, and for the individual who consumes it, provides beneficial nutrients and minimises potentially harmful elements. We have categorised nutritious foods into four different types: 1) high inherent nutritional value; 2) enhanced nutritional value; 3) some nutritional value; and 4) source of added nutrients.

GAIN defines a "safe" food as a food that does not contain a contaminant or other attribute that increases the probability of poor health outcomes, in the context where it is consumed and for the individual who consumes it. Foodborne hazards can be biological, chemical, or physical in nature, and food contamination can occur at any stage along the supply chain. We have articulated key food safety considerations and risk-reduction measures to improve safety along the value chain by food group.

GAIN is also increasingly seeking to promote sustainably produced foods and has identified ten environmental impact levers. Nutritious and safe foods have the potential to be produced sustainably, depending on practices adopted and their suitability to the local context. We are committed to assessing and balancing the emerging synergies and trade-offs between nutrition, food safety, and sustainable production.

KEY MESSAGES

- Regularly achieving internal consistency and providing guidance on the concept of "nutritious and safe foods" is crucial to the achievement of GAIN's mission and strategic objectives.

- A "nutritious" food is a food that provides beneficial nutrients and minimises potentially harmful elements. A "safe" food is a food that does not contain a contaminant or other attribute that increases the probability of poor nutrition and health outcomes.

- Considering contextual and individual characteristics is essential when defining "nutritious and safe foods."

- Nutritious and safe foods have the potential to be produced sustainably when adopting appropriate, fit-for-context production practices.

- Decision-making around nutritious and safe foods across GAIN's programmes is guided by the definition and examples provided here. 


\section{BACKGROUND AND OBJECTIVE}

GAIN's mission is to advance nutrition outcomes by improving the consumption of nutritious and safe foods for all people, especially the most vulnerable to malnutrition. Although our primary focus remains on nutrition and food safety, the organisation is increasingly seeking to promote nutritious and safe foods that are sustainably produced, in alignment with the Sustainable Development Goals.

Diets worldwide are shaped by food systems, which influence the demand, availability, affordability, convenience, and desirability of foods. GAIN aims to contribute to transforming food systems through three interlinked strategic objectives: 1) to improve the demand for nutritious and safe foods; 2 ) to increase the availability and affordability of nutritious and safe foods; 3 ) to strengthen the enabling environment to improve the consumption of nutritious and safe foods (1). Therefore, regularly achieving alignment and consistency across our programmes in the definition and use of the concept of "nutritious and safe foods" is crucial to our mission and strategy.

The purpose of this briefing paper, therefore, is to share the definition we use of "nutritious and safe foods (NSF)," present environmental impact levers of sustainable production, and provide relevant examples for guidance. This definition may be useful for others, either as the end point or starting point of one's own organisation's journey to define nutritious and safe foods.

\section{DEFINITION OF NUTRITIOUS AND SAFE FOODS AND RELATED GUIDANCE}

\section{NUTRITIOUS FOODS}

In alignment with the definition of the United Nations Food and Agriculture Organization (FAO) (2) and with the Committee on World Food Security Voluntary Guidelines (3), GAIN defines a "nutritious" food as a food that, in the context where it is consumed and for the individual who consumes it, provides beneficial nutrients (e.g., vitamins, major and trace minerals, unrefined complex carbohydrates, protein, unsaturated fats, essential amino acids, essential fatty acids, and dietary fibre) and minimises potentially harmful elements (e.g., transfats, excess quantities of saturated fats, free sugars, and sodium) Error! Bookmark not defined.

When categorising foods as more or less nutritious $(6,7)$, the contextual and target group qualification is essential because different population groups, in different contexts, have different nutritional requirements depending on a series of factors, such as age, gender, level of activity, life stage (e.g., pregnancy and lactation), genetics, health, and nutritional status (8). This is especially true for groups with increased nutritional needs (e.g., infants and young children, adolescents, women of reproductive age, pregnant and lactating women) (9), which can make a given food highly nutritious to them while being less so for others. For example, a one-year-old infant needs very energy-dense foods, while these might not be ideal for an adult or adolescent at risk of overweight/obesity.

To further illustrate the concept of a nutritious food for programmatic purposes, we have grouped nutritious foods into four broad types (Table 1). Aligned with our mission, these 
categories are considered in programmatic work with special emphasis given to the most nutritious foods possible for a given context and population group.

Table 1. Types of nutritious foods ${ }^{a, b}$

\begin{tabular}{|c|c|c|}
\hline Type & Description & $\begin{array}{l}\text { Examples of food groups } \\
\text { (non-exhaustive list) }\end{array}$ \\
\hline $\begin{array}{l}\text { High inherent } \\
\text { nutritional value }\end{array}$ & $\begin{array}{l}\text { Naturally contains micronutrients, dietary fibre, unrefined } \\
\text { complex carbohydrates, high quality protein and/or essential } \\
\text { fats in significant quantities. No major potentially harmful } \\
\text { elements }{ }^{c} \text { when consumed in recommended quantities by a } \\
\text { given group. }\end{array}$ & $\begin{array}{l}\text { Fruits and vegetables; whole } \\
\text { grains; legumes; nuts and seeds; } \\
\text { unsweetened dairy products; } \\
\text { eggs; fish; minimally processed } \\
\text { meat }\end{array}$ \\
\hline $\begin{array}{l}\text { Enhanced nutritional } \\
\text { value }\end{array}$ & $\begin{array}{l}\text { Foods with some inherent nutritional value that are made more } \\
\text { nutritious through the addition of nutrients (i.e. fortification) in } \\
\text { significant quantities or changes to the processing procedures. } \\
\text { No major potentially harmful elements }{ }^{\complement} \text { when consumed in } \\
\text { recommended quantities by a given group. }\end{array}$ & $\begin{array}{l}\text { Fortified staple grains/flours; } \\
\text { mitigating loss of germ and dietary } \\
\text { fibre in grain products }\end{array}$ \\
\hline $\begin{array}{l}\text { Some inherent } \\
\text { nutritional value }\end{array}$ & $\begin{array}{l}\text { Foods with some inherent nutritional value for which potentially } \\
\text { harmful elements }{ }^{c} \text { have been minimized when consumed in } \\
\text { recommended quantities by a given group. }\end{array}$ & $\begin{array}{l}\text { Low sugar dairy products; low } \\
\text { sodium processed meat; low sugar } \\
\text { fortified biscuits }\end{array}$ \\
\hline $\begin{array}{l}\text { Source of added } \\
\text { nutrients }\end{array}$ & $\begin{array}{l}\text { Condiments or supplements which enhance the nutritional value } \\
\text { of foods or diets to which they are added. }\end{array}$ & $\begin{array}{l}\text { lodized salt; fortified cooking oils; } \\
\text { micronutrient powders; protein- or } \\
\text { lipid-based supplements }\end{array}$ \\
\hline
\end{tabular}

In addition to the nutrient composition of foods, consideration should also be given to the nature, extent, and purpose of processing. Indeed, a growing body of emerging literature shows that ultra-processed foods (UPFs) (10) can be associated with increased risk of overweight and obesity and several diet-related non-communicable diseases (NCDs) (11-15) (Box 1).

- Processing plays a crucial role in improving food safety, enhancing nutritional value (e.g., fortification), increasing convenience (with positive implications on female labour participation and empowerment), and reducing food loss and waste.

- On the other hand, UPFs have been associated with increased risk of overweight and obesity and several diet-related NCDs. Indeed, most UPFs are very energy-dense and high in salt, sugars, and fats, and often lead to overconsumption due to their hyper-palatability (11-15).

- While recognising the positive implications of processing, GAIN highlights the importance of increasing consumption of unprocessed and minimally processed foods (10), as they provide not only essential nutrients but also a variety of nonessential compounds with potential beneficial effects on human health $(6,14,16-18)$.

\section{SAFE FOODS}

In alignment with the definition of food safety of the FAO and World Health Organization (WHO) (16), GAIN defines a "safe" food as a food that does not contain a contaminant or other attribute that increases the probability of poor health outcomes, in the context where it 
is consumed and for the individual who consumes it. Certain population groups have increased vulnerability to food safety hazards, including infants, young children, pregnant women, the elderly, and those with a compromised immune system due to an underlying illness (17). Foods that are generally regarded as 'safe' by this definition could still be unsafe for those with food intolerances or allergies.

Foodborne hazards include biological (pathogens and parasites), chemical including radiological (both natural, e.g., mycotoxins, and synthetic, e.g., misused food additives and residues of agrochemicals), and physical hazards (e.g., glass, plastic, or metal fragments) $(16,18)$. Food contamination can occur at any stage along the supply chain, from production to consumption. In practice, a safe food is that in which biological, chemical, and physical attributes that could cause adverse nutrition and health outcomes (19-21) do not exceed internationally agreed thresholds, as established by the Codex Alimentarius (22), which we use as a reference when appropriate (e.g., in the absence of national standards in a given country).

Table 2 summarises, by food group, key safety considerations and identified risk reduction measures when seeking to ensure food safety along the value chain (Table 2).

Table 2. Safety considerations and risk reduction measures by food groups

\begin{tabular}{|c|c|c|c|}
\hline Food group & $\begin{array}{l}\text { Level of } \\
\text { risk }^{\mathrm{a}}\end{array}$ & Food safety considerations & $\begin{array}{c}\text { Examples of risk reduction } \\
\text { measures }\end{array}$ \\
\hline $\begin{array}{l}\text { Grains and their } \\
\text { products }\end{array}$ & $\begin{array}{l}\text { Low- } \\
\text { Medium }\end{array}$ & $\begin{array}{l}\text { Grains can be contaminated with a range of mycotoxins (e.g., } \\
\text { aflatoxin, funomisin, deoxynivalenol) produced by fungi, } \\
\text { which can accumulate both before and after harvest. Grains } \\
\text { can accumulate heavy metals (e.g., lead, arsenic, cadmium) } \\
\text { from soil or irrigation water. Whole grains may be } \\
\text { contaminated with foreign matter of inorganic (e.g., stones) } \\
\text { and organic origins (e.g., soil, pests) and with bacterial } \\
\text { pathogens (e.g., Salmonella). }\end{array}$ & $\begin{array}{l}\text { Pre-harvest management } \\
\text { and disease control } \\
\text { practices, use clean irrigation } \\
\text { water, avoid contaminated } \\
\text { soil, sorting, proper storage } \\
\text { conditions, limit storage time }\end{array}$ \\
\hline $\begin{array}{l}\text { Roots and } \\
\text { tubers and their } \\
\text { products }\end{array}$ & $\begin{array}{l}\text { Low- } \\
\text { Medium } \\
\text { (variable) }\end{array}$ & $\begin{array}{l}\text { Roots and tubers often contain naturally occuring toxins, } \\
\text { such as solanine in potatoes and other nightshades and } \\
\text { cyanogenic compounds in cassava. }\end{array}$ & $\begin{array}{l}\text { Soak and cook before } \\
\text { consumption, store in the } \\
\text { dark, limit storage time }\end{array}$ \\
\hline $\begin{array}{l}\text { Groundnuts } \\
\text { and treenuts } \\
\text { and their } \\
\text { products }\end{array}$ & $\begin{array}{l}\text { Low- } \\
\text { Medium }\end{array}$ & $\begin{array}{l}\text { Groundnuts and treenuts can accumulate high levels of } \\
\text { aflatoxin, a potent mycotoxin. These commodities may be } \\
\text { contaminated with foreign matter and bacterial pathogens } \\
\text { (e.g., Salmonella). They may also accumulate heavy metals } \\
\text { from soil or irrigation water. Some treenuts may contain high } \\
\text { levels of naturally-occurning toxins like tannins and cyanides. }\end{array}$ & $\begin{array}{l}\text { Pre-harvest management } \\
\text { and disease-control } \\
\text { practices, use clean irrigation } \\
\text { water, avoid contaminated } \\
\text { soil, sorting, proper storage } \\
\text { conditions, limit storage time }\end{array}$ \\
\hline $\begin{array}{l}\text { Pulses and their } \\
\text { products }\end{array}$ & Low & $\begin{array}{l}\text { Pulses may be contaminated with foreign matter of inorganic } \\
\text { and organic origins. These commodities may also accumulate } \\
\text { heavy metals from the soil or irrigation water. }\end{array}$ & $\begin{array}{l}\text { Pre-harvest management } \\
\text { and disease-control } \\
\text { practices, use clean irrigation } \\
\text { water, avoid contaminated } \\
\text { soil, sorting }\end{array}$ \\
\hline $\begin{array}{l}\text { Fruits and } \\
\text { vegetables and } \\
\text { their products }\end{array}$ & $\begin{array}{l}\text { Medium- } \\
\text { High }\end{array}$ & $\begin{array}{l}\text { Fresh fruits and vegetables can be contaminated by several } \\
\text { bacterial, viral, protozoan, and helminth pathogens, such as } \\
\text { E. coli and Salmonella, Hepatitis A virus, Cyclospora), which } \\
\text { are often associated with unclean water or fecal matter. } \\
\text { Preserved fruits and vegetables (especially canned) can be } \\
\text { contaminated with botulinum toxin, produced by } \\
\text { Clostridium botulinum bacteria. Fruits and vegetables may } \\
\text { also be contaminated with pesticide residues. }\end{array}$ & $\begin{array}{l}\text { Pre-harvest practices, } \\
\text { washing, cooking, } \\
\text { refrigeration, freezing, avoid } \\
\text { cross-contamination, } \\
\text { irradiation, limit storage } \\
\text { time, fermentation and } \\
\text { preservation }\end{array}$ \\
\hline $\begin{array}{l}\text { Milk and dairy } \\
\text { products }\end{array}$ & $\begin{array}{l}\text { Medium- } \\
\text { High }\end{array}$ & $\begin{array}{l}\text { Raw milk and dairy products can be contaminated by several } \\
\text { bacterial pathogens also found in cattle, e.g., } \\
\text { pathogenicE.coli and Salmonella. Processed dairy products } \\
\text { can be contaminated by Listeria monocytogenes, which can } \\
\text { grow at refrigeration temperatures. Milk can also contain } \\
\text { residues of veterinary drugs. }\end{array}$ & $\begin{array}{l}\text { Boiling, pasteurisation, } \\
\text { refrigeration, freezing, avoid } \\
\text { cross-contamination, limit } \\
\text { storage time }\end{array}$ \\
\hline
\end{tabular}




\begin{tabular}{|c|c|c|c|}
\hline Food group & $\begin{array}{l}\text { Level of } \\
\text { risk }^{\mathrm{a}}\end{array}$ & Food safety considerations & $\begin{array}{c}\text { Examples of risk reduction } \\
\text { measures }\end{array}$ \\
\hline $\begin{array}{l}\text { Eggs and their } \\
\text { products }\end{array}$ & $\begin{array}{l}\text { Medium- } \\
\text { High }\end{array}$ & $\begin{array}{l}\text { Eggs can be contaminated with bacterial pathogens } \\
\text { (particularly Salmonella) and lipid-soluble environmental } \\
\text { contaminants (e.g., dioxins). }\end{array}$ & $\begin{array}{l}\text { Pre-harvest hygiene, } \\
\text { cooking, avoid cracked } \\
\text { eggs, refrigeration, limit } \\
\text { storage time }\end{array}$ \\
\hline $\begin{array}{l}\text { Fish and } \\
\text { shellfish and } \\
\text { their products }\end{array}$ & High & $\begin{array}{l}\text { Fish and shellfish can bioaccumulate environmental } \\
\text { contaminants (e.g., mercury and ciguatoxin). A number of } \\
\text { bacterial pathogens are also prevalent in raw fish and } \\
\text { shellfish, such as Vibrio, Salmonella and Listeria; as well as } \\
\text { helminths such as roundworms (e.g., Phocanema/cod worm) } \\
\text { and tapeworms (e.g., Diphyllobothrium). Some fish produce } \\
\text { toxins (e.g., tetrodotoxin in pufferfish). }\end{array}$ & $\begin{array}{l}\text { Cooking, buy live from } \\
\text { reputable sources, } \\
\text { refrigeration, freezing, avoid } \\
\text { cross-contamination, avoid } \\
\text { products with pungent } \\
\text { odors, drying, smoking }\end{array}$ \\
\hline $\begin{array}{l}\text { Meat and its } \\
\text { products }\end{array}$ & High & $\begin{array}{l}\text { Raw meat (including poultry) can contain bacterial pathogens } \\
\text { such as E. coli, Salmonella, and Campylobacter. Meat can } \\
\text { also contain parasites, such as Taenia spp. (tapeworms) and } \\
\text { Trichinella spp. (roundworms). }\end{array}$ & $\begin{array}{l}\text { Cooking, refrigeration, } \\
\text { freezing, avoid cross- } \\
\text { contamination, drying, } \\
\text { smoking }\end{array}$ \\
\hline Fats and oils & Low & $\begin{array}{l}\text { Oxidation of fatty acids in oil results in ketones, alcohols, and } \\
\text { aldehydes that can be toxic at high concentrations. Animal } \\
\text { fats may harbour bacterial pathogens found in meat. }\end{array}$ & $\begin{array}{l}\text { Avoid prolonged heating, } \\
\text { avoid multiple fryings, avoid } \\
\text { sunlight, hygiene, heat } \\
\text { treatment, avoid cross- } \\
\text { contamination }\end{array}$ \\
\hline $\begin{array}{l}\text { Spices and } \\
\text { condiments }\end{array}$ & $\begin{array}{l}\text { Low- } \\
\text { Medium }\end{array}$ & $\begin{array}{l}\text { Spices (e.g., chilis) can be contaminated with aflatoxin, a } \\
\text { potent mycotoxin; bacterial pathogens (e.g., Salmonella); } \\
\text { and inorganic and organic foreign matter (e.g., hair, insects, } \\
\text { stones, etc.). }\end{array}$ & $\begin{array}{l}\text { Drying, sorting, proper } \\
\text { packaging and handling, } \\
\text { irradiation, proper storage } \\
\text { conditions }\end{array}$ \\
\hline $\begin{array}{l}\text { Foods or } \\
\text { supplements } \\
\text { for particular } \\
\text { nutritional uses }\end{array}$ & Variable & $\begin{array}{l}\text { Complementary foods for infants and young children made } \\
\text { from maize or groundnuts may be contaminated with } \\
\text { aflatoxin and other mycotoxins. }\end{array}$ & $\begin{array}{l}\text { Exclusive and continued } \\
\text { breastfeeding, avoid maize } \\
\text { and groundnuts in } \\
\text { complementary foods, } \\
\text { source safe ingredients }\end{array}$ \\
\hline
\end{tabular}

\section{CONSIDERATIONS FOR SUSTAINABLE PRODUCTION}

In this briefing paper, the term production is used to encompass the whole production chain from farm level (raw ingredients) to processing and packaging of the finished product. GAIN's Environmental Guidelines present the following environmental impact levers of sustainable production for consideration in programme decision-making: 1) strategy, governance, and risk management; 2) environmental regulation compliance; 3) supplier/partner environmental maturity; 4) energy; 5) emissions; 6) biodiversity and land use; 7) soil; 8) materials; 9) water and effluents; and 10) waste.

While acknowledging the importance of this concept, we recognise that there is no one-sizefits-all model for how to sustainably produce a given food commodity. Nutritious and safe foods have the potential of being produced sustainably depending on methods and practices adopted, as well as contextual characteristics. As an example, while intensive production of animal-source foods like meat, fish, eggs, and dairy, as well as intensive crop monocultures for human consumption $(23,24)$, can have significant negative impacts on the environment, there are many opportunities for more regenerative and sustainable production of livestock and crops, particularly when methods are appropriate for the local context and ecological environment (24-28). The level of processing also has implications for the ability to produce foods sustainably, with UPFs of both animal and plant origin generally being associated with more negative environmental consequences $(22,29-32)$. 
While GAIN's priority is promoting nutritious and safe foods, the organisation is committed to assessing and balancing any synergies and trade-offs between nutrition, food safety, and sustainable production, in alignment with the FAO-WHO recommendation to quantify and address such trade-offs (23).

\section{CONCLUSIONS}

Categorising the nutritional value and level of food safety risk of foods is very complex, as both depend on multiple inherent and external factors, and there are often ambiguities and inconsistencies across different definitions, standards, and criteria for classification (7). To address such complexity, keep up-to-date with emerging evidence, and regularly facilitate the operationalisation of the nutritious and safe foods definition, GAIN has an Nutritious and Safe Food Definition working group that has developed several tools for programmatic guidance. This set of tools are dynamic: regularly updated, adapted, and added to as needed.

In conclusion, this briefing paper has shared the definition GAIN uses of nutritious and safe food, presented environmental impact levers of sustainable production, and provided relevant examples for guidance. The definition presented here helps inform decision-making processes across GAIN's programmes, towards the achievement of our mission and strategy to advance nutrition outcomes by improving the consumption of nutritious and safe foods for all people. 


\section{REFERENCES}

1. GAIN. GAIN Strategic Plan 2017-2022 [Internet]. 2017. Available from:

https://www.gainhealth.org/sites/default/files/publications/documents/gain-organisationalstrategy-17-22.pdf

2. The State of Food Security and Nutrition in the World 2020 [Internet]. FAO, IFAD, UNICEF, WFP and WHO; 2020 [cited 2021 Apr 7]. Available from:

http://www.fao.org/documents/card/en/c/ca9692en

3. Committee on World Food Security. CFS Voluntary Guidelines on Food Systems and Nutrition. 2021.

4. Drewnowski A. Concept of a nutritious food: toward a nutrient density score. The American Journal of Clinical Nutrition. 2005 Oct 1;82(4):721-32.

5. Katz DL, Doughty K, Njike V, Treu JA, Reynolds J, Walker J, et al. A cost comparison of more and less nutritious food choices in US supermarkets. Public Health Nutrition. 2011 Sep;14(9):1693-9.

6. Neufeld LM, Hendriks S, Hugas M. Healthy diet: A definition for the United Nations Food Systems Summit 2021 (Scientific Group for the UNFSS). 2021 Mar;11.

7. HLPE. Nutrition and food systems: A report by The High Level Panel of Experts on Food Security and Nutrition. 2017;(\#12):152.

8. Dimensions of need - Human nutrition: Key to health and development [Internet]. [cited 2021 Apr 7]. Available from: http://www.fao.org/3/u8480e/u8480e04.htm

9. Dimensions of need - People and populations at risk [Internet]. [cited 2021 Apr 7]. Available from:

http://www.fao.org/3/u8480e/U8480E05.htm\#People\%20and\%20populations\%20at\%20risk

10. Monteiro CA, Cannon G, Levy R, Moubarac J-C, Jaime P, Martins AP, et al. NOVA. The star shines bright. World Nutrition. 2016 Jan 7;7(1-3):28-38.

11. Hall KD, Ayuketah A, Brychta R, Cai H, Cassimatis T, Chen KY, et al. Ultra-Processed Diets Cause Excess Calorie Intake and Weight Gain: An Inpatient Randomized Controlled Trial of Ad Libitum Food Intake. Cell Metabolism. 2019 Jul 2;30(1):67-77.e3.

12. Askari M, Heshmati J, Shahinfar H, Tripathi N, Daneshzad E. Ultra-processed food and the risk of overweight and obesity: a systematic review and meta-analysis of observational studies. International Journal of Obesity. 2020 Oct;44(10):2080-91.

13. Lane MM, Davis JA, Beattie S, Gómez-Donoso C, Loughman A, O’Neil A, et al. Ultraprocessed food and chronic noncommunicable diseases: A systematic review and metaanalysis of 43 observational studies. Obesity Reviews. 2021;22(3):e13146.

14. Beal T, White JM, Arsenault JE, Okronipa H, Hinnouho G-M, Murira Z, et al. Micronutrient gaps during the complementary feeding period in South Asia: A Comprehensive Nutrient Gap Assessment. Nutr Rev. 2021 Mar 9;79(Supplement_1):26-34. 
15. Ultra-processed foods, diet quality, and health using the NOVA classification system | Global Forum on Food Security and Nutrition (FSN Forum) [Internet]. [cited 2021 Apr 26]. Available from: http://www.fao.org/fsnforum/resources/fsn-resources/ultra-processed-foodsdiet-quality-and-health-using-nova-classification

16. FAO/WHO. Assuring food safety and quality: Guidelines for strengthening national food control systems [Internet]. Rome: FAO; 2003. (Food and Nutrition Paper). Available from: http://www.fao.org/3/y8705e/y8705e.pdf

17. WHO. Food safety Factsheet [Internet]. 2020 [cited 2021 Apr 7]. Available from: https://www.who.int/news-room/fact-sheets/detail/food-safety

18. Food and Drug Administration, Center for Food Safety and Applied Nutrition. Hazard Analysis and Risk-Based Preventive Controls for Human Food: Guidance for Industry [Internet]. 2018. Available from: https://www.fda.gov/media/100002/download

19. Roosen J. Marketing of safe food through labeling. Journal of Food Distribution Research. 2003 Feb 1;34.

20. Hennessy D, Roosen J, Jensen H. Systemic failure in the provision of safe food. Food Policy. 2003;28(1):77-96.

21. Grunert KG. Food quality and safety: consumer perception and demand. European Review of Agricultural Economics. 2005;32(3):369-91.

22. CODEXALIMENTARIUS FAO-WHO. Codex texts: Standards [Internet]. [cited 2021 Apr 8]. Available from: http://www.fao.org/fao-who-codexalimentarius/codex-texts/liststandards/en/

23. Lark TJ, Spawn SA, Bougie M, Gibbs HK. Cropland expansion in the United States produces marginal yields at high costs to wildlife. Nat Commun. 2020 Sep 9;11(1):4295.

24. Kremen C, Miles A. Ecosystem Services in Biologically Diversified versus Conventional Farming Systems: Benefits, Externalities, and Trade-Offs. Ecology and Society [Internet]. 2012 [cited 2021 Oct 14];17(4). Available from: https://www.jstor.org/stable/26269237

25. Rowntree J. Ecosystem Impacts and Productive Capacity of a Multi-Species Pastured Livestock System. Frontiers in Sustainable Food Systems. 2020;

26. Beal T. Achieving dietary micronutrient adequacy in a finite world. One Earth. 2021 Sep 17;4(9):1197-200.

27. Beal T, Nordhagen S. Animal-source foods for human and planetary health_GAIN Briefing Paper Series 2. GAIN; 2020.

28. Beal T, Massiot E, Arsenault JE, Smith MR, Hijmans RJ. Global trends in dietary micronutrient supplies and estimated prevalence of inadequate intakes. PLOS ONE. 2017 Apr 11;12(4):e0175554.

29. Paraskevi S. The neglected environmental impacts of ultra-processed foods. The Lancet-planetary health; 2020. 
30. Hendrie GA, Baird D, Ridoutt B, Hadjikakou M, Noakes M. Overconsumption of Energy and Excessive Discretionary Food Intake Inflates Dietary Greenhouse Gas Emissions in Australia. Nutrients. 2016 Nov;8(11):690.

31. Fardet A, Rock E. Ultra-Processed Foods and Food System Sustainability: What Are the Links? Sustainability. 2020 Jan;12(15):6280.

32. van Vliet S, Kronberg SL, Provenza FD. Plant-Based Meats, Human Health, and Climate Change. Frontiers in Sustainable Food Systems. 2020;4:128.

33. Codex Alimentarius. GUIDELINES FOR USE OF NUTRITION AND HEALTH CLAIMS [Internet]. 2013. Available from: http://www.fao.org/fao-who-codexalimentarius/shproxy/en/?lnk=1\&url=https\%253A\%252F\%252Fworkspace.fao.org\%252Fsites\%252Fcodex\% 252FStandards\%252FCXG\%2B23-1997\%252FCXG_023e.pdf

34. European Commission. Labelling and Nutrition [Internet]. Food Safety. 2016 [cited 2021 Apr 12]. Available from:

https://ec.europa.eu/food/safety/labelling_nutrition/claims/nutrition_claims_en

35. FAO, WHO. Codex Alimentarius Standards on Nutrition and Labelling [Internet]. Available from: http://www.fao.org/fao-who-codexalimentarius/thematic-areas/nutritionlabelling/en/

36. CODEXALIMENTARIUS FAO-WHO. General Principles for the Addition of Essential Nutrients to Foods [Internet]. 1987. Available from: http://www.fao.org/fao-whocodexalimentarius/shproxy/en/?|nk=1\&url=https\%253A\%252F\%252Fworkspace.fao.org\%252Fsites\%252Fcodex\% 252FStandards\%252FCXG\%2B9-1987\%252FCXG_009e_2015.pdf 


\section{ANNEX}

Table 3: Definitions, standards, and criteria in relation to terms used in Table 1 on 'Types of nutritious foods'

\begin{tabular}{|c|c|c|}
\hline Term/expression & Definitions, standards, and criteria & Source \\
\hline Unprocessed foods & $\begin{array}{l}\text { Edible parts of plants (fruits, seeds, leaves, stems, roots, tubers) or of } \\
\text { animals (muscle, offals, eggs, milk), and also fungi, algae, and water, after } \\
\text { separation from nature. }\end{array}$ & $\begin{array}{l}\text { NOVA classification } \\
\text { system, used in } \\
\text { FAO and WHO } \\
\text { documents (10) }\end{array}$ \\
\hline $\begin{array}{l}\text { Minimally } \\
\text { processed foods }\end{array}$ & $\begin{array}{l}\text { Unprocessed foods that have been submitted to processing (e.g., cleaning, } \\
\text { removal of inedible fractions, portioning, refrigeration, freezing, pasteurisation, } \\
\text { fermenting, pre-cooking, drying, skimming, bottling, canning, and packaging) } \\
\text { that does not substantially alter nutritional properties of the original food. }^{\text {a }}\end{array}$ & $\begin{array}{l}\text { NOVA classification } \\
\text { system (10) }\end{array}$ \\
\hline Processed foods & $\begin{array}{l}\text { Products obtained by adding salt, oil, and/or sugar to unprocessed or minimally } \\
\text { processed foods, through preservation methods such as canning, bottling, or } \\
\text { non-alcoholic fermentation. Processed foods may also contain additives to } \\
\text { prolong product duration, preserve original properties, and/or prevent } \\
\text { microorganism proliferation. }^{\text {a }}\end{array}$ & $\begin{array}{l}\text { NOVA classification } \\
\text { system (10) }\end{array}$ \\
\hline $\begin{array}{l}\text { Ultra-processed } \\
\text { foods (UPFs) }\end{array}$ & $\begin{array}{l}\text { Formulations of ingredients resulting from a series of (often sophisticated) } \\
\text { industrial processes, including fractioning of whole foods into substances, } \\
\text { chemical modifications of these compounds, and assembly of unmodified and } \\
\text { modified food substances. UPFs frequently involve the use of industrial } \\
\text { techniques such as extrusion, moulding and pre-frying, 'cosmetic additives' to } \\
\text { increase product palatability, and sophisticated packaging. Sugar, oils and fats, } \\
\text { and salt are often used in combination, as well as substances of no or rare } \\
\text { culinary use (i.e., high fructose com syrup, hydrogenated or interesterified oils, } \\
\text { protein isolates), cosmetic additives (i.e., flavours, flavour enhancers, colours, } \\
\text { emulsifiers, sweeteners, thickeners, anti-foaming, bulking, carbonating, foaming, } \\
\text { gelling, and glazing agents) and additives to prolong product duration, preserve } \\
\text { original properties, and/or prevent microorganism proliferation. }{ }^{\text {a }}\end{array}$ & $\begin{array}{l}\text { NOVA classification } \\
\text { system (10) }\end{array}$ \\
\hline Low (saturated) fat & $\begin{array}{l}\text { The 'low fat' nutrient content claim can be attributed to foods that have no more } \\
\text { than } 3 \mathrm{~g} \text { of fats per } 100 \mathrm{~g} \text { (solids) or } 1.5 \mathrm{~g} \text { per } 100 \mathrm{ml} \text { (liquids). } \\
\text { The 'low saturated fat' claim can be attributed to foods in which the sum of } \\
\text { saturated fats and trans-fats (if present) does not exceed } 1.5 \mathrm{~g} \text { per } 100 \mathrm{~g} \text { (solids) } \\
\text { or } 0.75 \mathrm{~g} \text { per } 100 \mathrm{ml} \text { (liquids) and does not provide more than } 10 \% \text { of energy. }\end{array}$ & $\begin{array}{l}\text { Codex Alimentarius } \\
\text { (33) }\end{array}$ \\
\hline Trans-fat & $\begin{array}{l}\text { The maximum limit for trans-fat (other than trans-fat naturally occurring in fat of } \\
\text { animal origin) in food which is intended for the final consumer and supply to } \\
\text { retail is } 2 \mathrm{~g} \text { per } 100 \mathrm{~g} \text { of fat. }\end{array}$ & $\begin{array}{l}\text { European } \\
\text { Commission }{ }^{b}(34)\end{array}$ \\
\hline (Very) Low sodium & $\begin{array}{l}\text { The 'low sodium' or 'very low sodium' nutrient content claims can be attributed } \\
\text { to foods that have no more than } 0.12 \mathrm{~g} \text { sodium per } 100 \mathrm{~g} \text { or } 0.04 \mathrm{~g} \text { per } 100 \mathrm{~g} \text {, } \\
\text { respectively. }\end{array}$ & $\begin{array}{l}\text { Codex Alimentarius } \\
\text { (33) }\end{array}$ \\
\hline Low sugar & $\begin{array}{l}\text { The 'low sugar' claim can be attributed to foods that have no more than } 5 \mathrm{~g} \text { of } \\
\text { sugar per } 100 \mathrm{~g} \text { (solids) or } 1.5 \mathrm{~g} \text { per } 100 \mathrm{ml} \text { (liquids). }\end{array}$ & $\begin{array}{l}\text { European } \\
\text { Commissionb (34) }\end{array}$ \\
\hline $\begin{array}{l}\text { Source of/High } \\
\text { protein }\end{array}$ & $\begin{array}{l}\text { Foods can be claimed to be a 'source of protein' if they provide at least } 10 \% \text { of } \\
\text { the Nutrient Reference Value (NRV) for protein per } 100 \mathrm{~g} \text { (solids) or } 5 \% \text { of the } \\
\text { NRV per } 100 \mathrm{ml} \text { (liquids) or } 5 \% \text { of the NRV per } 100 \mathrm{kcal} \text { or } 10 \% \text { of the NRV per } \\
\text { serving. } \\
\text { Foods can be claimed to be 'high protein' if they contain two times the values } \\
\text { for the 'source of protein' claim. }\end{array}$ & $\begin{array}{l}\text { Codex Alimentarius } \\
\text { (35) }\end{array}$ \\
\hline $\begin{array}{l}\text { Source of/High } \\
\text { vitamins and } \\
\text { minerals }\end{array}$ & $\begin{array}{l}\text { Foods can be claimed to be a 'source of vitamins and minerals' if they provide at } \\
\text { least } 15 \% \text { of the NRVs per } 100 \mathrm{~g} \text { (solids) or } 7.5 \% \text { of the NRVs per } 100 \mathrm{ml} \text { (liquids) } \\
\text { or } 5 \% \text { of the NRVs per } 100 \mathrm{kcal} \text { or } 15 \% \text { of the NRVs per serving. } \\
\text { They can be claimed to be 'high in vitamins and minerals' if they contain two } \\
\text { times the values for the 'source of vitamins and minerals' claim. }\end{array}$ & $\begin{array}{l}\text { Codex Alimentarius } \\
\text { (35) }\end{array}$ \\
\hline $\begin{array}{l}\text { Source of/High } \\
\text { dietary fibre }\end{array}$ & $\begin{array}{l}\text { Foods can be claimed to be a 'source of dietary fibre' if they contain at least } 3 \mathrm{~g} \\
\text { of dietary fibre per } 100 \mathrm{~g} \text { or } 1.5 \mathrm{~g} \text { per } 100 \mathrm{kcal} \text { or } 10 \% \text { of the daily reference } \\
\text { value per serving. } \\
\text { They can be claimed to be 'high dietary fibre' if they contain two times the } \\
\text { values for the 'source of dietary fibre' claim. }\end{array}$ & $\begin{array}{l}\text { Codex Alimentarius } \\
\text { (35) }\end{array}$ \\
\hline $\begin{array}{l}\text { High (poly or } \\
\text { mono) unsaturated } \\
\text { fat }\end{array}$ & $\begin{array}{l}\text { The 'high unsaturated fat' claim can be attributed to foods in which at least } 70 \% \\
\text { of the fatty acids present in the product derive from unsaturated fat and in which } \\
\text { unsaturated fat provides at least } 20 \% \text { of energy of the product. }\end{array}$ & $\begin{array}{l}\text { European } \\
\text { Commission }{ }^{b}(34)\end{array}$ \\
\hline
\end{tabular}


The 'high polyunsaturated fat' claim can be attributed to foods in which at least $45 \%$ of the fatty acids present in the product derive from polyunsaturated fat and in which polyunsaturated fat provides at least $20 \%$ of energy of the product. The 'high monounsaturated fat' claim can be attributed to foods in which at least $45 \%$ of the fatty acids present in the product derive from monounsaturated fat and in which monounsaturated fat provides at least $20 \%$ of energy of the product.

\begin{tabular}{|c|c|c|}
\hline $\begin{array}{l}\text { Source of/High } \\
\text { omega-3 }\end{array}$ & $\begin{array}{l}\text { Foods can be claimed to be a 'source of omega- } 3 \text { fatty acids' if they provide at } \\
\text { least } 0.3 \mathrm{~g} \text { of alpha-linolenic acid per } 100 \mathrm{~g} \text { and per } 100 \mathrm{kcal}, \text { or at least } 40 \mathrm{mg} \\
\text { of the sum of eicosapentaenoic acid and docosahexaenoic acid per } 100 \mathrm{~g} \text { and } \\
\text { per } 100 \mathrm{kcal} \text {. } \\
\text { They can be claimed to be 'high omega- } 3 \text { fatty acids' if they if they contain two } \\
\text { times the values for the 'source of omega-3 fatty acids' claim. }\end{array}$ & $\begin{array}{l}\text { European } \\
\text { Commission }{ }^{b}(34)\end{array}$ \\
\hline $\begin{array}{l}\text { Enhanced } \\
\text { nutritional value }\end{array}$ & $\begin{array}{l}\text { Foods with enhanced nutritional value can be obtained through the addition of } \\
\text { nutrients (i.e., fortification) in significant quantities. National and regional } \\
\text { authorities are responsible for determining significant amounts for the addition } \\
\text { of essential nutrients to foods and may want to consider the criteria for the } \\
\text { 'source of' nutrient content claim as a reference point. }\end{array}$ & $\begin{array}{l}\text { Codex Alimentarius } \\
\text { (36) }\end{array}$ \\
\hline
\end{tabular}

